[Agr. Biol. Chem., Vol. 34, No. 3, p. 335 342, 1970]

\title{
Formation of Valine in the Presence of Sodium Acrylate Monomer by Glutamic Acid Producing Bacteria
}

\author{
By Takeshi Kawamura and Isao TakedA \\ Technical Research Laboratory, Asahi Chemical Industry, Co., Lid., \\ Nakadaicho, Itabashi-ku, Tokyo \\ Received July 31, 1969
}

\begin{abstract}
Glutamic acid producing bacteria accumulated a large amount of valine in the presence of the excess biotin, when sodium acrylate monomer (Na-AM) was added at the earlier phase of culture. Brevibacterium roseum ATCC 13825, particularly, accumulated the large amount of valine among bacteria tested and the conditions of valine accumulation by this strain were investigated.

The most effective addition time of $\mathrm{Na}-\mathrm{AM}$ was at the earlier phase of logarithmic phase. The optimal concentration of Na-AM for the accumulation of valine was 1.0 per cent $(\mathrm{v} / \mathrm{v})$. Most effective nitrogen sources were the combination of 1.0 per cent urea and 0.2 per cent ammonium sulphate. The additions of $\mathrm{Mn}^{2+}$ and $\mathrm{Fe}^{2+}$ increased valine accumulation. By the excess concentration of biotin for growth, $20 \mu \mathrm{g} / \mathrm{liter}$ or more, did. not affected valine accumulation, while the presence of the suboptimal condition of biotin for growth was not good for the formation of valine even in the presence of Na-AM. The accumulation of valine reached $9.0 \mathrm{mg} / \mathrm{ml}$ from $75.0 \mathrm{mg} / \mathrm{ml}$ of glucose in the presence of $50 \mu \mathrm{g} /$ liter of biotin and 1.0 per cent $(\mathrm{v} / \mathrm{v})$ of $\mathrm{Na}-\mathrm{AM}$.

This strain possessed considerable activity of valine formation regardless of the addition of $\mathrm{Na}-\mathrm{AM}$ and promoted the accumulation of valine by the addition of Na-AM.
\end{abstract}

It has been known that various metabolites were accumulated by various culture conditions. ${ }^{11}$ The accumulation of valine by microorganisms has been studied by several groups of workers in recent years, ${ }^{2 \sim 6)}$ but it has not been known that bacteria accumulated valine in the addition of sodium acrylate monomer (Na-AM) on fermentation process.

1) $T$. Uemura and $Y$. Asada, 7 th International Congress of Biochemistry (1967, VIII, Tokyo), Abstract G-11.

2) P.D. Bragg and W.J. Polglase, J. Bacteriol., 88, 1006 (1964).

3) S. Sugizaki, Nippon Nogeikagaku Kaishi, 34, 153 (1960).

4) Y. Takamura, M. Ito, Y. Fujii and T. Uemura, Amino Acids, 4, 52 (1961).

5) S. Udaka and S. Kinoshita, J. Gen. Appl. Microbiol., 5, 1959 (1960).

6) K. Nakayama, S. Kitada and S. Kinoshita, Amino Acids, 2, 77 (1960).
During the course of an investigation on the utilization of Na-AM by microorganisms, it was found that bacteria producing glutamic acid under the suboptimal condition of biotin for growth accumulated a large amount of valine under the excess of biotin for growth and the addition of Na-AM in the earlier phase of the growth.

Glutamic acid producing bacteria, generally, accumulated a large amount of glutamic acid under the suboptimal condition of biotin for growth, but none of amino acids were accumulated under the excess condition of biotin. It has been known that glutamic acid was also accumulated under the excess condition of biotin if penicillin is added in the earlier phase of culture." However, when Na-AM

7) T. Matsuo, M. Kubo, W. Hashida and $\mathrm{S}$. Teramoto, Amino Acids, 7, 51 (1963). 
was added in the earlier phase of culture under such a excess condition of biotin for growth, bacterial growth was not so much inhibited and valine and alanine were accumulated in the logarithmic phase of culture, but at the stationary phase alanine was assimilated and only a large amount of valine was accumulated.

It has been reported that Na-AM inhibited the propionate formation from pyruvate by Micrococcus lactilyticus ${ }^{8}$ and also the $\beta$-oxidation of alkanes by Pseudomonas."

The present paper describes valine production by glutamic acid producing bacteria by the addition of Na-AM at the earlier phase of the fermentation process which contains the excess biotin for the growth of bacteria in the medium.

\section{MATERIALS AND METHODS}

Microorganisms. Bacteria used are shown in Table I.

Table I. Microorganisms of Valine Formation IN THE PRESENCE of Na-AM

Brevibacterium divaricatum NRRL 2311

Brevibacterium roseum ATCC 13825

Brevibacterium flavum ATCG 13826

Brevibacterium lactofermentum ATCG 13869

Micrococcus glutamicus ATCC 13059

Microbacterium flavum var. glutamicum ATCG 13693

Microbacterium ammoniaphilum ATCC 13058

Culture. Composition of media are shown in Table II. One or two loops of agar slant culture were inoculated in $500 \mathrm{ml}$ shaking flask containing $50 \mathrm{ml}$ of the seed medium. The inoculated medium was incubated at $30^{\circ} \mathrm{C}$ for $24 \mathrm{hr}$ on a reciprocal shaker. One per cent $(v / v)$ of the seed cell suspension was inoculated in each shaking flask containing $50 \mathrm{ml}$ of the basal medium. The inoculated medium was in-

8) H. R. Whiteley and E.J. Ordal, J. Bacteriol., 74, 331 (1957).

9) G. J. E. Thijsse, Biochem. Biophis. Acta, 84, 195 (1964).
TABlE II. Composition of MEDia

Seed medium

Glucose $1.0 \%$, peptone $1.0 \%$, meat extract $1.0 \%$, $\mathrm{NaCl} 0.5 \%$, ( $\mathrm{pH} \mathrm{7.0)}$.

Basal medium

$\begin{array}{lllr}\text { Glucose } & 5.0 \% & \text { Thiamine-HCl } & 500 \\ \left(\mathrm{NH}_{4}\right)_{2} \mathrm{SO}_{4} & 0.2 \% & \text { Ribotlavin } & 500 \\ \text { Urea } & 1.0 \% & \text { PABA } & 20 \\ \mathrm{KH}_{2} \mathrm{PO}_{4} & 0.2 \% & \text { Nicotinic acid } & 1000 \\ \mathrm{MgSO}_{4} \cdot 7 \mathrm{H}_{2} \mathrm{O} & 0.04 \% & \text { Ca-pantothenate } & 500 \\ \mathrm{FeSO}_{4} \cdot 7 \mathrm{H}_{2} \mathrm{O} & 0.001 \% & \text { Pyridoxin } & 500 \\ \mathrm{MnSO}_{4} \cdot 7 \mathrm{H}_{2} \mathrm{O} & 0.001 \% & \text { Folic acid } & 10 \\ & (\mathrm{pH} \mathrm{7.0)} & \text { Biotin } & 50\end{array}$

The seed culture was carried out at $30^{\circ} \mathrm{C}$ for $24 \mathrm{hr}$ on a reciprocal shaker. The fermentation culture was carried out at $30^{\circ} \mathrm{C}$ for $8 \mathrm{hr}$ on a reciprocal shaker, to which was inoculated $1.0 \%(\mathrm{v} / \mathrm{v})$ of seed suspension. Then, Na-AM was added and the fermentation culture was continued for $64 \mathrm{hr}$.

cubated at $30^{\circ} \mathrm{C}$. Then, Na-AM was added at the time described and the culture was continued for $72 \mathrm{hr}$.

Assay. Bacterial growth was determined by the measurement of optical density at $610 \mathrm{~m} \mu$ to the cell suspension prepared by diluting to twenty folds the culture broth with $0.1 \mathrm{~N}$ hydrochloric acid solution.

Paper chromatography of amino acids was performed by the solvent system of $n$-butanol:acetic acid : water $(25: 11: 4, v / v)$. Amino acids developed were visualized by spraying 2 per cent ninhydrinacetone solution and heating at $85^{\circ} \mathrm{C}$ for $5 \mathrm{~min}$. The spots of amino acids were cutted off and eluted with 70 per cent ethanol solution and optical dencity was measured at $562 \mathrm{~m} \mu$.

Glucose was determined by Somogyi's micro-copper method.10)

Preparation of intact cells. Cells of Brev. roseum ATCC 13825 strain were harvested from the culture broth which had been incubated on the basal medium at $30^{\circ} \mathrm{C}$ for $8 \mathrm{hr}$ and then to the medium 1.0 per cent $(\mathrm{v} / \mathrm{v}) \mathrm{Na}-\mathrm{AM}$ was added and the culture was continued at $30^{\circ} \mathrm{C}$ for $16 \mathrm{hr}$. The harvested cells were washed twice with 0.85 per cent saline and again with $\mathrm{M} / 15$ phosphate buffer ( $\mathrm{pH} 7.2$ ), and resuspended in $\mathrm{M} / 15$

10) M. Somogyi, J. Biol. Chem., 195, 19 (1952). 
phosphate buffer ( $\mathrm{pH}$ 7.2). Cell suspension was prepared to show 1.0 of optical dencity at $610 \mathrm{~m} \mu$ with $5 \mathrm{~mm}$ width cuvett by dilution. On the other hand, control cell suspension was prepared from the cells which incubated on the basal medium without $\mathrm{Na}$ AM.

The reaction was carried out in a test tube at $30^{\circ} \mathrm{C}$. Two $\mathrm{ml}$ of $\mathrm{M} / 15$ phosphate buffer ( $\mathrm{pH}$ 7.2) were poured in the test tube, which contained each of $444 \mu$ moles glucose, $150 \mu$ moles $\mathrm{NH}_{4} \mathrm{CI}, 16.2 \mu$ moles $\mathrm{MgSO}_{4} \cdot 7 \mathrm{H}_{2} \mathrm{O}$ and a certain volume of $\mathrm{Na}-\mathrm{AM}$. Finally, $2 \mathrm{ml}$ of cell suspension was combined to the reaction mixture and the reaction was carried out at $30^{\circ} \mathrm{C}$ for $5.5 \mathrm{hr}$. Amino acids produced were determined by paper chromatography. Amino acids in the cells were excreted by the method of Mandelstrami11 and determined by the paper chromatography described above.

Material. $\mathrm{Na}-\mathrm{AM}$ was obtained from Toagosei Chem. Ind. Co., Ltd. and its solution contained 33 per cent of sodium acrylate monomer.

\section{RESULTS}

Valine formation by various glutamic acid producing bacteria

Table III shows the results of valine formation in the basal medium with the addition of $\mathrm{Na}-\mathrm{AM}$ by various glutamic acid producing bacteria. After the basal medium was inoculated with 1.0 per cent $(\mathrm{v} / \mathrm{v})$ of cell suspension as seed culture and incubated at $30^{\circ} \mathrm{C}$ for $8 \mathrm{hr}, 1.0$ per cent $(\mathrm{v} / \mathrm{v}) \mathrm{Na}-\mathrm{AM}$ was added and the culture was continued at $30^{\circ} \mathrm{G}$ for another $64 \mathrm{hr}$. Amino acids formed were assayed by the paper chromatography. All bacteria used grew well and valine was accumulated in the culture fluid.

As for other amino acids, some amounts of alanine and glutamic acid were accumulated in the logarithmic phase of culture, but in the stationary phase these amino acids were not detected and valine was the only amino acid accumulated.

Brev. roseum ATCG 13825 strain which ac-

11) J. Mandelstram, Biochem. J., 69, 103 (1958),
Table III. Valine Formation by Various Glutamic Acid Producing Bacteria

\begin{tabular}{lccc}
\hline Test organisms & $\begin{array}{c}\text { Growth } \\
(\text { O.D. }\end{array}$ & Final pH & $\begin{array}{c}\text { Valine } \\
(\mathrm{mg} / \mathrm{ml})\end{array}$ \\
\hline $\begin{array}{l}\text { Brev. divaricutum } \\
\quad \text { NRRL 2311 }\end{array}$ & 0.845 & 8.8 & 0.8 \\
$\begin{array}{l}\text { Brev. roseum ATCC } \\
\quad \text { 13825 }\end{array}$ & 0.640 & 8.6 & 6.7 \\
$\begin{array}{l}\text { Brev. flavum ATCC } \\
\quad \text { 13826 }\end{array}$ & 0.959 & 8.8 & 3.4 \\
$\begin{array}{l}\text { Brev. lactofermentum } \\
\text { ATCC 13869 }\end{array}$ & 0.800 & 8.8 & 1.0 \\
$\begin{array}{l}\text { Micrococcus glutamicus } \\
\text { ATCC 13059 }\end{array}$ & 0.700 & 8.8 & 3.0 \\
$\begin{array}{l}\text { Microb. flavum var. } \\
\text { glutamicum ATCC } \\
\text { 13693 }\end{array}$ & 0.665 & 8.8 & 3.2 \\
$\begin{array}{l}\text { Microb. ammoniaphilum } \\
\text { ATCC 13058 }\end{array}$ & 0.670 & 7.4 & 1.7 \\
\hline
\end{tabular}

The culture conditions were the same as Table II.

cumulated the largest amounts of valine was used through the following experiments.

Condition of valine formation by the addition of $\mathrm{Na}-\mathrm{AM}$ in Brev. roseum ATCC 13825

1) Addition time of $N a-A M$. Table IV shows the relationship between valine formation and the addition time of $\mathrm{Na}-\mathrm{AM}$. The

TABLE IV. EFfects of AdDition Time of Na-AM on Valine Formation

$\begin{array}{cccc}\begin{array}{c}\text { Addition } \\ \text { time } \\ \text { (hr) }\end{array} & \begin{array}{c}\text { Growth } \\ \text { (O.D.) }\end{array} & \text { Final pH } & \begin{array}{c}\text { Valine } \\ (\mathrm{mg} / \mathrm{ml})\end{array} \\ 4.0 & 0.044 & 9.0 & - \\ 5.0 & 0.059 & 9.0 & - \\ 6.0 & 0.076 & 9.0 & - \\ 7.0 & 0.465 & 9.0 & 2.1 \\ 8.0 & 0.690 & 8.8 & 8.6 \\ 9.0 & 0.710 & 8.6 & 6.4 \\ 10.0 & 0.685 & 9.0 & 7.2 \\ 11.0 & 0.665 & 9.0 & 5.5 \\ \text { None } & 0.825 & 9.0 & + \\ \end{array}$

Medium and the cultural condition were the same as Table II and $1.0 \%(\mathrm{v} / \mathrm{v}) \mathrm{Na}-\mathrm{AM}$ was added. The experimental conditions were the same unless otherwise specified. 
culture medium was incubated at $30^{\circ} \mathrm{C}$ for $72 \mathrm{hr}$. Na-AM inhibited bacterial growth and if 1.0 per cent $(\mathrm{v} / \mathrm{v})$ Na-AM was added at zero time, no growth was detected. In Table IV. 1.0 per cent $(\mathrm{v} / \mathrm{v}) \mathrm{Na}-\mathrm{AM}$ was added at every one hour intervals from 4 to $11 \mathrm{hr}$ after the inoculation. If Na-AM was added at the earlier phase than 4 to $6 \mathrm{hr}$ of culture, bacterial growth was inhibited and valine was not accumulated. In the addition of $\mathrm{Na}-\mathrm{AM}$ at $7 \mathrm{hr}$ after inoculation, bacterial cells showed half growth of the control in which medium $\mathrm{Na}-\mathrm{AM}$ was omitted and valine was accumulated only $2.1 \mathrm{mg} / \mathrm{ml}$. When Na-AM was added at $8 \mathrm{hr}$ after inoculation valine was accumulated $8.6 \mathrm{mg} / \mathrm{ml}$. Under this condition accumulation of valine was the largest amount in culture fluid.

According to this data $\mathrm{Na}-\mathrm{AM}$ was added at $8 \mathrm{hr}$ after the inoculation in the following experiments.

2) The concentration of $N a-A M$. Table $\mathrm{V}$ shows the results of valine formation at various concentrations of $\mathrm{Na}-\mathrm{AM}$ added. When 2.0 per cent $(\mathrm{v} / \mathrm{v})$ Na-AM was added to the medium, bacterial growth was inhibited and the accumulation of valine decreased, whereas bacterial growth was not changed in the concentration of Na-AM less than 1.0 per cent $(\mathrm{v} / \mathrm{v}) \mathrm{Na}-\mathrm{AM}$, but the accumulation of valine decreased in the lower concentration of $\mathrm{Na}$ AM.

Table $V$. EFFects of Concentration of Na-AM ON VALINE FORMATION

\begin{tabular}{cccc}
$\begin{array}{c}\text { Na-AM } \\
\%(\mathrm{v} / \mathrm{v})\end{array}$ & $\begin{array}{c}\text { Growth } \\
\text { (O.D.) }\end{array}$ & Final pH & $\begin{array}{c}\text { Valine } \\
(\mathrm{mg} / \mathrm{ml})\end{array}$ \\
\hline 2.0 & 0.398 & 8.4 & 3.2 \\
1.0 & 0.690 & 8.8 & 6.5 \\
0.5 & 0.720 & 9.0 & 3.8 \\
0.1 & 0.735 & 9.0 & 1.9 \\
0.05 & 0.725 & 9.0 & 1.5 \\
None & 0.735 & 9.0 & + \\
\hline
\end{tabular}

Medium and the cultural conditions were the same as Table II.
This data shows that the optimal concentration of Na-AM existed, and 1.0 per cent $(v / v)$ $\mathrm{Na}-\mathrm{AM}$ was added in the following experiments.

3) The concentration of glucose. Table VI shows the results of valine formation on various glucose concentration. Optimal concentration of glucose was 7.5 per cent. The higher concentration of glucose caused the marked decreased of valine formation, though it caused the increase of bacterial growth.

TABLE VI. EFFEcts of CONCENTRation OF Glucose on Valine Formation

\begin{tabular}{cccc}
\hline $\begin{array}{c}\text { Glucose } \\
(\%)\end{array}$ & $\begin{array}{c}\text { Growth } \\
\text { (O.D.) }\end{array}$ & Final pH & $\begin{array}{c}\text { Valine } \\
(\mathrm{mg} / \mathrm{ml})\end{array}$ \\
\hline 5.0 & 0.640 & 6.6 & 6.7 \\
7.5 & 0.854 & 6.8 & 8.7 \\
10.0 & 0.967 & 5.0 & 5.6 \\
15.0 & 0.928 & 5.0 & 0.9 \\
\hline
\end{tabular}

Medium and the cultural conditions were the same as Table II and 1.0\% (v/v) Na-AM was added.

4) Effect of nitrogen sources. Tables VII and VIII show the relationship between valine formation and nitrogen sources.

In Table VII, several kinds of inorganic

Table VII. EfFects of Nitrogen SOURCeS ON VALINE FORMATION

\begin{tabular}{lcccc}
\hline Nitrogen sources & $\%$ & $\begin{array}{c}\text { Growth } \\
\text { (O.D. }\end{array}$ & Final pH & $\begin{array}{c}\text { Valine } \\
(\mathrm{mg} / \mathrm{ml})\end{array}$ \\
\hline$\left(\mathrm{NH}_{4}\right)_{2} \mathrm{SO}_{4}$ & 1.0 & 0.118 & 5.0 & - \\
& 1.5 & 0.121 & 5.0 & - \\
$\mathrm{NH}_{4} \mathrm{Cl}$ & 1.0 & 0.117 & 5.0 & - \\
& 1.5 & 0.102 & 5.0 & - \\
$\mathrm{NH}_{4} \mathrm{NO}_{3}$ & 1.0 & 0.130 & 5.0 & - \\
& 1.5 & 0.128 & 5.0 & - \\
$\left(\mathrm{NH}_{4}\right)_{2} \mathrm{HPO}_{4}$ & 1.0 & 0.357 & 5.0 & - \\
& 1.5 & 0.425 & 5.0 & - \\
$\left(\mathrm{NH}_{2}\right)_{2} \mathrm{CO}$ & 1.0 & 0.695 & 9.0 & 4.8 \\
& 1.5 & 0.328 & 8.8 & 2.3 \\
\hline
\end{tabular}

Medium and the cultural conditions were the same as Table II and $1.0 \%(\mathrm{v} / \mathrm{v}) \mathrm{Na-AM}$ was added. 
TABLE VIII. EFFECTS OF NITROGen SOURCES ON VALINE FORMATION

\begin{tabular}{|c|c|c|c|c|}
\hline Nitrogen sources & $\%$ & $\begin{array}{l}\text { Growth } \\
\text { (O.D.) }\end{array}$ & Final $\mathrm{pH}$ & $\begin{array}{l}\text { Valine } \\
(\mathrm{mg} / \mathrm{ml})\end{array}$ \\
\hline Urea & 1.0 & 0.695 & 9.0 & 4.8 \\
\hline $\begin{array}{l}\text { Urea } 1.0 \% \\
\quad+\left(\mathrm{NH}_{4}\right)_{2} \mathrm{SO}_{4}\end{array}$ & $\begin{array}{l}0.2 \\
0.5\end{array}$ & $\begin{array}{l}0.665 \\
0.231\end{array}$ & $\begin{array}{l}6.4 \\
6.4\end{array}$ & $\begin{array}{c}8.6 \\
+\end{array}$ \\
\hline $\begin{array}{l}\text { Urea } 1.0 \% \\
+\mathrm{NH}_{4} \mathrm{Cl}\end{array}$ & $\begin{array}{l}0.2 \\
0.5\end{array}$ & $\begin{array}{l}0.610 \\
0.645\end{array}$ & $\begin{array}{l}8.0 \\
7.2\end{array}$ & $\begin{array}{l}5.0 \\
1.8\end{array}$ \\
\hline $\begin{array}{l}\text { Urea } 1.0 \% \\
++\mathrm{NH}_{4} \mathrm{NO}_{3}\end{array}$ & $\begin{array}{l}0.2 \\
0.5\end{array}$ & $\begin{array}{l}0.690 \\
0.590\end{array}$ & $\begin{array}{l}8.0 \\
6.6\end{array}$ & $\begin{array}{l}4.3 \\
4.1\end{array}$ \\
\hline $\begin{array}{l}\text { Urea } 1.0 \% \\
\quad+\left(\mathrm{NH}_{4}\right)_{2} \mathrm{HPO}_{4}\end{array}$ & $\begin{array}{l}0.2 \\
0.5\end{array}$ & $\begin{array}{l}0.560 \\
0.510\end{array}$ & $\begin{array}{l}8.8 \\
8.8\end{array}$ & $\begin{array}{l}2.8 \\
3.5\end{array}$ \\
\hline
\end{tabular}

Medium and the cultural conditions were the same as Table II and $1.0 \%(\mathrm{v} / \mathrm{v}) \mathrm{Na}-\mathrm{AM}$ was added.

nitrogen sources were added as the sole nitrogen source. It was shown that the most effective nitrogen source was urea, and the addition of 1.0 per cent urea accumulated $4.8 \mathrm{mg} / \mathrm{ml}$ of valine in culture fluid. But 1.5 per cent urea decreased the accumulation of valine. On the other nitrogen sources such as ammonium sulphate, $\mathrm{NH}_{4} \mathrm{Cl}$ and $\mathrm{NH}_{4} \mathrm{NO}_{3}$, little growth was detected and none of valine was accumulated. Although cells were considerably grown in the case of ammonium phosphate, none of valine was accumulated. This is probably due to low $\mathrm{pH}$ in fermentation process. Table VIII shows the additive effects of 1.0 per cent urea and 0.2 per cent or 0.5 per cent other nitrogen sources. The combination of 1.0 per cent urea and 0.2 per cent ammonium sulphate was the most effective nitrogen sources for valine accumulation. In this condition valine was accumulated $8.6 \mathrm{mg} / \mathrm{ml}$. However, the addition of 0.5 per cent ammonium sulphate decreased cell growth and none of valine was accumulated. For the prolonged lag phase, cell growth was probably inhibited by the high concentration of Na-AM. Other nitrogen sources were not so effective as ammonium sulphate for valine accumulation.

5) Effects of organic nitrogen sources. Table IX shows the effects of organic nitrogen sources for valine formation. The addition of each organic nitrogen source shown in Table IX increased cell growth, but the accumulation of valine was not increased by the addition of 1.0 per cent casamino acid or 1.0 per cent yeast extract and decreased by the addition of other organic nitrogen sources.

TABLE IX. EFFECTS OF ORganIC Nitrogen SOURCES on Valine Formation

\begin{tabular}{lcccc}
$\begin{array}{c}\text { Organic nitrogen } \\
\text { sources }\end{array}$ & \%o & $\begin{array}{c}\text { Growth } \\
\text { (O.D.) }\end{array}$ & Final pH & $\begin{array}{c}\text { Valine } \\
(\mathrm{mg} / \mathrm{ml})\end{array}$ \\
\cline { 1 - 5 } Peptone & 0.2 & 1.028 & 9.0 & + \\
Yeast extract & 1.0 & 1.160 & 8.6 & 1.8 \\
\multirow{2}{*}{ Casamino acid } & 0.2 & 1.143 & 8.6 & 3.4 \\
Meat extract & 1.0 & 0.770 & 8.4 & 6.4 \\
& 1.0 & 0.570 & 8.0 & 6.3 \\
Corn steep liquor & 0.2 & 1.260 & 8.6 & 6.8 \\
& 1.0 & 1.128 & 8.8 & 2.5 \\
None & 1.0 & 0.780 & 9.0 & 1.5 \\
& - & 0.665 & 6.4 & 8.6 \\
\hline
\end{tabular}

Medium and the cultural conditions were the same as Table II and $1.0 \%(\mathrm{v} / \mathrm{v}) \mathrm{Na}-\mathrm{AM}$ was added. Organic nitrogen sources as indicated were added to the basal medium.

6) Effects of metal ions. Tables $\mathrm{X}$ and $\mathrm{XI}$ show the effects of metal ions for valine formation.

The experimental methods were as follows; bacteria were cultured and harvested by centrifugation and washed twice with the metal free basal medium and resuspended in the same medium. Then cells were finally suspended at the same optical density as that of culture broth. This cell suspension was inoculated into the basal medium which contained each metal ion and the inoculated medium was incubated by the same method as Table II.

Manganese ion was the most suitable metal 
Table $X$. EFFEcts of Metal IONS on Valine formation

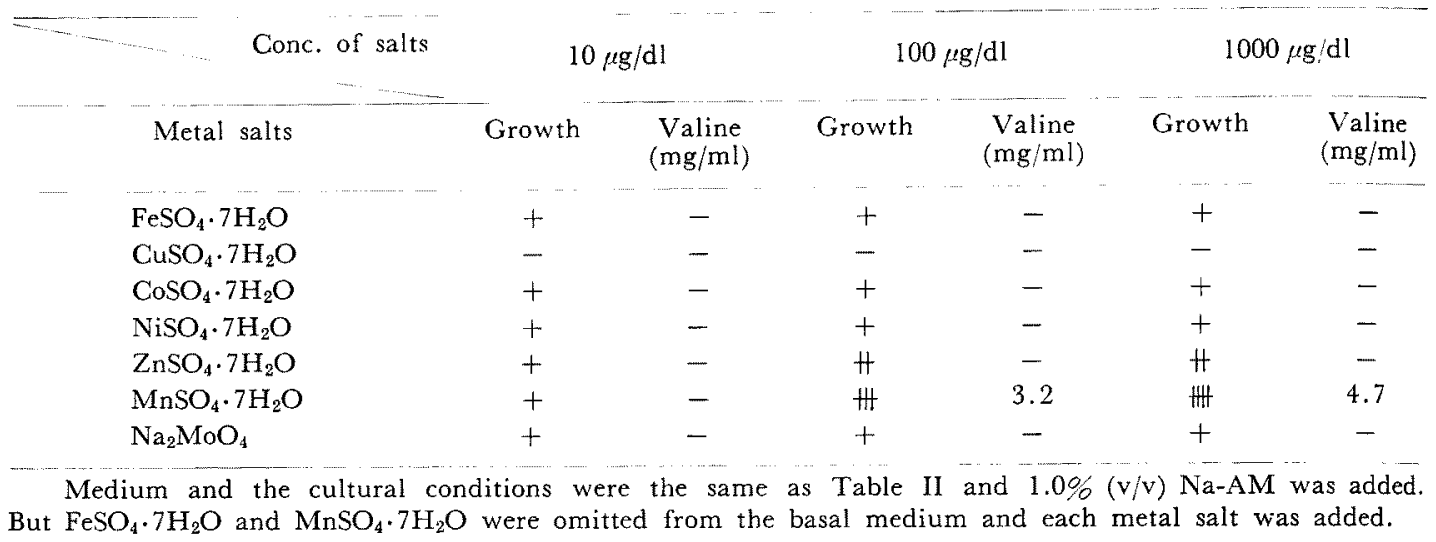

TABle XI. EFFEcts of METAL IONS ON VALINE. FORMATION

\begin{tabular}{lccc} 
Metal ions & Growth & Final pH & $\begin{array}{c}\text { Valine } \\
(\mathrm{mg} / \mathrm{ml})\end{array}$ \\
$\mathrm{Mn}^{2+}$ & $\ldots$ & 7.8 & 4.7 \\
$\mathrm{Mn}^{2+}+\mathrm{Fe}^{2+}$ & Ht & 8.4 & 6.0 \\
$\mathrm{Mn}^{2+}+\mathrm{Cu}^{2+}$ & + & - & - \\
$\mathrm{Mn}^{2+}+\mathrm{Zn}^{2+}$ & H & 6.6 & 2.4 \\
$\mathrm{Mn}^{2+}+\mathrm{Co}^{2+}$ & H & 8.8 & + \\
$\mathrm{Mn}^{2+}+\mathrm{Ni}^{2+}$ & H & 8.8 & + \\
$\mathrm{Mn}^{2+}+\mathrm{MoO}_{4}{ }^{2-}$ & H & 7.0 & 2.4 \\
\hline
\end{tabular}

Medium and the cultural conditions were the same as Table II and $1.0 \%(\mathrm{v} / \mathrm{v}) \mathrm{Na}-\mathrm{AM}$ was added. But $\mathrm{FeSO}_{4} \cdot 7 \mathrm{H}_{2} \mathrm{O}$ and $\mathrm{MnSO}_{4} \cdot 7 \mathrm{H}_{2} \mathrm{O}$ were omitted from the basal medium, and each metal ion was added $1000 \mu \mathrm{g} / \mathrm{dl}$ as salt.

ion for valine formation (Table $\mathrm{X}$ ). In other metal ions, cells were slowly grown and lag time of the growth was very long in comparison with the basal medium which was shown in Table II. Na-AM, therefore, was too high concentration to grow well in the addition of these metal ions and inhibited cell growth (Tables IV and X).

Table XI shows the additive effects of $\mathrm{Mn}^{2+}$ and other metal ions. The most effective pair of metal ions was $\mathrm{Mn}^{2+}$ and $\mathrm{Fe}^{2+}$ No effect was observed on another pairs and $\mathrm{Cu}^{2+}$, particularly, inhibited cell growth.

7) The concentration of biotin. It has been known that glutamic acid producing bacteria control evidently glutamic acid formation by the concentration of biotin. ${ }^{121}$ Then, the concentration of biotin for valine formation was investigated, and Table XII shows the effects of each concentration of biotin for valine formation in the addition of Na-AM.

In the addition of 0.1 per cent $(v / v)$ Na-AM, glutamic acid was accumulated in the suboptimal concentration of biotin for growth, while little amino acids accumulated in the excess concentration of biotin for growth. In the addition of 1.0 per cent $(\mathrm{v} / \mathrm{v}) \mathrm{Na}-\mathrm{AM}$, the bacterial growth was poor and none of amino acids were accumulated under the suboptimal condition of biotin for growth, but bacteria showed the good growth and the large amounts of valine were accumulated under the optimal addition of biotin. $8.6 \mathrm{mg} / \mathrm{ml}$ of valine was accumulated in the presence of $50 \mu \mathrm{g} /$ liter of biotin.

8) Valine formation by intact cells. It was found that the addition of Na-AM during fermentation accumulated a large amount of valine. The relationship between the addition of Na-AM and the formation of valine was examined by intact cells.

12) K. Tanaka, S. Akita, K. Kimura and S. Kinoshita, Amino Acids, 1, 62 (1959). 
Table XII. Concentration of Biotin on Amino acid Formation

\begin{tabular}{|c|c|c|c|c|c|c|}
\hline \multirow{2}{*}{$\begin{array}{l}\mathrm{Na}-\mathrm{AM} \\
\%(\mathrm{v} / \mathrm{v})\end{array}$} & \multirow{2}{*}{$\begin{array}{c}\text { Biotin } \\
(\mu \mathrm{g} / \text { liter })\end{array}$} & \multirow{2}{*}{$\begin{array}{l}\text { Growth } \\
\text { (O.D.) }\end{array}$} & \multirow[t]{2}{*}{ Final $\mathrm{pH}$} & \multicolumn{3}{|c|}{ Amino acids (mg/ml) } \\
\hline & & & & Glu & Ala & Val \\
\hline \multirow[t]{4}{*}{0.1} & 2.0 & 0.365 & 5.0 & 15.7 & - & - \\
\hline & 5.0 & 0.390 & 5.0 & 12.3 & + & - \\
\hline & 20.0 & 0.760 & 9.0 & + & + & + \\
\hline & 50.0 & 0.765 & 9.0 & + & + & + \\
\hline \multirow{4}{*}{1.0} & 2.0 & 0.360 & 8.0 & + & + & + \\
\hline & 5.0 & 0.398 & 8.0 & + & + & + \\
\hline & 20.0 & 0.775 & 8.0 & + & + & 5.5 \\
\hline & 50.0 & 0.690 & 9.0 & + & + & 8.6 \\
\hline
\end{tabular}

Medium and the cultural conditions were the same as Table II and Na-AM was added at $8 \mathrm{hr}$ after incubation. But biotin was omitted from the basal medium and each concentration of biotin was added.

Table XIII. Amino Acids Formation with Intact Gells

\begin{tabular}{|c|c|c|c|c|c|c|c|}
\hline \multirow[b]{2}{*}{$\begin{array}{l}\mathrm{Na}-\mathrm{AM} \\
(\%, \mathrm{v} / \mathrm{v})\end{array}$} & \multirow[t]{2}{*}{$\begin{array}{l}\text { Condition of } \\
\text { cultured cell }\end{array}$} & \multicolumn{3}{|c|}{ None of Na-AM } & \multicolumn{3}{|c|}{$\begin{array}{l}\text { Addition of Na-AM } \\
1.0 \%(\mathrm{v} / \mathrm{v}) \text { at } 8 \mathrm{hr}\end{array}$} \\
\hline & & $\begin{array}{l}\text { Glutamic } \\
\text { acid }\end{array}$ & $\begin{array}{l}\text { Alanine } \\
(\mu \mathrm{g} / \mathrm{ml})\end{array}$ & Valine & $\underset{\text { acid }}{\text { Glutamic }}$ & $\begin{array}{l}\text { Alanine } \\
(\mu \mathrm{g} / \mathrm{ml})\end{array}$ & Valine \\
\hline c & 0 & - & 400 & 225 & 560 & 180 & - \\
\hline & 0.1 & - & 520 & 700 & - & 370 & 800 \\
\hline & 0.5 & - & 375 & 300 & - & - & 200 \\
\hline & 1.0 & - & 167 & 133 & - & - & - \\
\hline Pool ami & ino acids & 500 & 116 & - & 233 & 83 & - \\
\hline
\end{tabular}

Incubation mixture, which composition described in Materials and Methods, was reciprocally aerated at $30^{\circ} \mathrm{C}$ for $5.5 \mathrm{hr}$ in a test tube.

Table XIII shows the results by the use of intact cells. Valine was accumulated by both the intact cells which were prepared from $\mathrm{Na}-\mathrm{AM}$ containing medium and $\mathrm{Na}-\mathrm{AM}$ omitting medium, if $\mathrm{Na}-\mathrm{AM}$ was added in the reaction. Alanine was also accumulated at the same time. The optimal concentration of $\mathrm{Na}-\mathrm{AM}$ added was found for the accumulation of valine and alanine. The cells which were prepared by $\mathrm{Na}-\mathrm{AM}$ omitting medium formed valine at the reaction in the absence of $\mathrm{Na}-\mathrm{AM}$, so this strain have possessed the activity of valine formation and its activity was promoted by the addition of Na-AM. The cells which were prepared by Na-AM added medium accumulated glutamic acid in the absence of $\mathrm{Na}-\mathrm{AM}$, but this cells ac- cumulated valine in the addition of $\mathrm{Na}-\mathrm{AM}$ as shown in Table XIII. It is interesting that metabolic conversion was caused by the addition of Na-AM. Amounts of amino acids in the cells prepared from Na-AM containing medium were less in comparison with that of Na-AM omitting medium. It is also interesting that $\mathrm{Na}-\mathrm{AM}$ relates the permeation of the materials through the cell membrane or the inhibition of the accumulation of intracellular amino acids.

9) Time course of valine formation. Figure 1 shows the results of time course of valine formation. When Na-AM was added in the earlier time of logarithmic phase, cells were slowly grown and reached stationary phase 


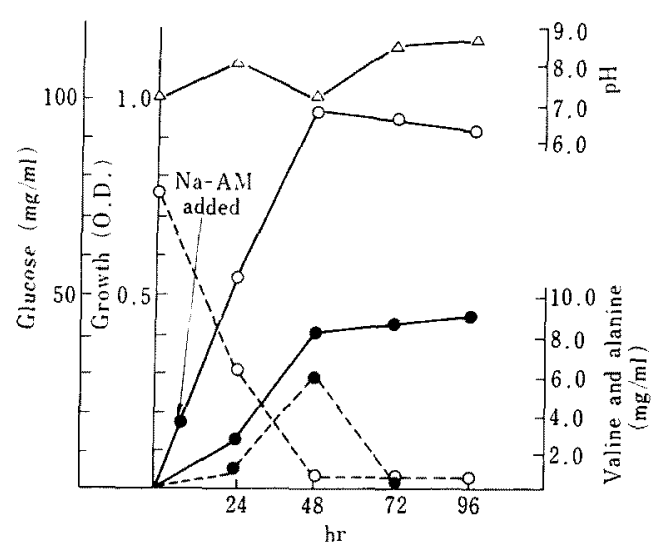

FIG. 1. Time Course of Valine Formation.

Medium and the cultural conditions were the same as Table II.

O-O growth, $\mathrm{O}-\mathrm{O}$ glucose, $\Delta-\Delta \mathrm{pH}$,

- valine, alanine.

at about $48 \mathrm{hr}$. If $\mathrm{Na}-\mathrm{AM}$ was omitted, cells were reached stationary phase in $12 \mathrm{hr}$. It is suggested that this slow growth was due to the addition of Na-AM. $8.0 \mathrm{mg} / \mathrm{ml}$ valine accumulated at $48 \mathrm{hr}$ and reached to $9.0 \mathrm{mg} / \mathrm{ml}$ at $96 \mathrm{hr}$. Alanine was accumulated at the same time and reached to $6.0 \mathrm{mg} / \mathrm{ml}$ at $48 \mathrm{hr}$, but none of alanine was detected at the end of fermentation. None of keto acids, which were checked by 2,4-dinitrophenylhydrazine, was found.

\section{DISCUSSION}

It was found that glutamic acid producing bacteria accumulated a large amount of valine when Na-AM was added at the earlier phase of culture. At the same time alanine was accumulated at the logarithmic phase, but at the end of fermentation alanine was assimilat- ed and did not detected. If Na-AM was added at the lag phase of culture, bacterial growth was inhibited for its bacteriostatic action. There were the most effective addition time and the optimal concentration of Na-AM for the accumulation of valine, that is, when 1.0 per cent $(\mathrm{v} / \mathrm{v}) \mathrm{Na}-\mathrm{AM}$ was added at $8 \mathrm{hr}$ after incubation, the largest amount of valine was accumulated.

Most effective nitrogen sources for valine accumulation was the combination of 1.0 per cent urea and 0.2 per cent ammonium sulfate. Metal ion, particularly $\mathrm{Mn}^{2+}$, was necessary to the accumulation of valine, and the most effective pair of metal ions for valine accumulation was $\mathrm{Mn}^{2+}$ and $\mathrm{Fe}^{2+}$ Valine accumulation was not affected by the excess concentration of biotin, $20 \mu \mathrm{g} /$ liter or more, for growth.

On the other hand, glutamic acid producing bacteria possessed considerable activity of valine accumulation, so $\mathrm{Na}-\mathrm{AM}$ can be assumed to promote the activity of valine formation. It can be also assumed that $\mathrm{Na}-\mathrm{AM}$ inhibited the metabolism of TCA cycle and pyruvate fell in valine formation, because Na-AM inhibited the synthesis of $\mathrm{C}_{4}$ dicarboxylic acids. ${ }^{81}$

The action of Na-AM was assumed to relate the permeation of amino acids through the cell membrane or the inhibition of the accumulation of intracellular amino acids, because amounts of amino acids in the cells which were prepared from Na-AM containing medium were less in comparison with that of cells which were prepared from $\mathrm{Na}$ AM omitting medium (Table XIII).

Acknowlegement. The authors wish to thank Dr. R. Wakasa and Dr. K. Nagamatsu for many helpful discussions and suggestions during this work. 